\section{Misconduct: lack of action provokes web accusations}

SIR - As the webmaster of New Threads (www.xys.org) - the website "at the centre of concerns over daims of misconduct", according to your Special Report "Named and shamed" (Nature 441, 392-393; 2006) I cannot agree with your comment that "some fear persecution reminiscent of that used in the Cultural Revolution".

The Cultural Revolution was started by Chairman Mao in 1966 and formally ended with his death in 1976. Although 30 years have passed, the memory of this calamity is still vivid in many Chinese minds - it is understandable that some fear the tragedy might someday recur. But it is ridiculous to compare free speech on the Internet to the violence of the Cultural Revolution, which was controlled by a dictator, allowed for no freedom and included governmental persecution of 'class enemies.' I find it ironic that 120 Chinese-American scientists and self-appointed human-rights advocates have signed an open letter appealing to the Chinese government to suppress media and public opinions: they still need to learn what free speech and human rights mean.

I agree that China should establish an official channel to investigate allegations of misconduct. In fact, I made this suggestion as early as 2001, in a speech to the Chinese students and scholars association at the University of California, San Diego (see www.xys.org/xys/netters/Fang-Zhouzi/ science/yanjiang.txt). But before this channel exists, and to make sure it functions properly after it is established, free press and free speech are indispensable.

Shi-min Fang

New Threads Chinese Cultural Society,

PO Box 26194, San Diego, California 92196, USA

\section{Misconduct: exposure is not like Cultural Revolution}

SIR - Your Special Report (Nature 441, 392-393; 2006) and Editorial " Finding fraud in China $a^{a}$ (Nature 441, 549-550; 2006) express deep concern about accusations of scientific misconduct in China. You rightly point out that it should be the government's greatest priority to crack down on scientific misconduct, if it is rife.

The New Threads website covers wide areas such as literature and popular science. It is well known for posting accusations of all types of scientific misconduct, and providing a forum for people to discuss their concerns. There are good reasons for the popularity of the website among intellectuals and the general public. It is the motivation of those condemning it that needs to be questioned.
It is misleading to suggest that high-profile researchers could be persecuted through accusations made against them on the Internet, or to compare this to the Cultural Revolution. I witnessed the violence of the Cultural Revolution in my childhood. My parents were abused by the Red Guard because of their family, education and professional background. I cried when I saw crosses marking their names in posters and cartoons.

The Cultural Revolution was a mass movement organized by the country's leader to crack down on his opponents. New Threads is just a platform without any official power: openness is the key to its success. It has become a portal for the grass roots who are ignored by official channels, such as university authorities, when they report misconduct. Internet debate and the resultant public attention can act as a warning to people attempting to violate research ethics. This is nothing like the horror of the Cultural Revolution.

\section{Zheng Huang}

Radiation Oncology Department, University of Colorado at Denver and Health Sciences Center, Aurora, Colorado 80045, USA

\section{Misconduct: Chinese funding body unmoved}

SIR - I can believe you had difficulties contacting the National Natural Science Foundation of China (NSFC) for your Special Report (Nature 441, 392-393; 2006). As executive editor of the Journal of Clinical Investigation, I recently attempted to contact the NSFC to help us investigate an allegation of misconduct in a study the journal had accepted from Chinese authors.

A whistle-blower's e-mail from someone at the authors' institution indicated that data in the study were fabricated. The authors had collaborated with the dean of their university, so we were unsure whether contacting the institution would result in an unbiased investigation. As China does not have a supervisory body akin to the US Office of Research Integrity, we thought the NSFC which had funded the study - would help.

Despite multiple e-mails, in English and in Chinese, the NSFC did not respond. Through a personal contact, I was put in touch with the director of the division that granted funding to the senior author. After repeated e-mails, I received the following: "I received the letter you written and we discussed the things you written to him. We have to say it is very difficult for us to determine whether their work is true. Because there are more than 50,000 proposals and about 10,000 grants supported in the Foundation every year. So we think maybe you have to find other way to make sure the thing."

This statement indicates that the NSFC does not prioritize the policing of misconduct.
If it is not responsible for, or is too busy to investigate, the researchers it funds, then surely such behaviour is tolerated and endorsed?

The story has a sad ending. When confronted, the senior author claimed to have misplaced the primary data during a move between laboratories. In addition, the co-corresponding author (who signed our authorship agreement form upon acceptance, and who wrote to our office inquiring about the publication date) later claimed never to have seen more than the title of the work and asked to be removed as a co-author. The authors have now withdrawn their article.

Alongside Xin-Yuan Fu and his 120 co-signatories, I too eagerly await a response from Chinese authorities on whether they will establish a body to police misconduct. Ushma Savla Neill

Joumal of Clinical Investigation, Columbia University College of Physicians and Surgeons, Box 57A, New York, New York 10032, USA

\section{Education and training put Iran ahead of richer states}

SIR - We read with interest your News report "Arab state pours oil profits into science" (Nature 441, 132-133; 2006). Other countries in the Gulf have also tried to spend oil money on setting up branches of Western universities, which is of arguable value when the infrastructure and the basic prerequisites of scientific research do not exist. Educating and training the personnel capable of doing research, as you describe in Qatar, is more important than spending on research and buying sophisticated equipment. Focusing on research and inviting scientists from overseas may lead to some short-term results, but it does not guarantee sustainable development without a solid, internal educational base.

Iran is a good example of a country that has made considerable advances through focusing on education and training. Despite sanctions in almost all aspects of research during the past 27 years, Persian scientists have been producing cutting-edge science. Their publication rate in international journals has quadrupled during the past decade. Although it is still low compared with the developed countries, this puts Iran in the first rank of Islamic countries.

Considering the country's brain drain and its poor political relationship with the West, Iran's scientific community remains productive, even while economic sanctions make it hard for universities to purchase equipment or send people to the United States to attend scientific meetings. Mohammad Reza Mohebbi ${ }^{\star}$, Mehri Mohebbi† "Department of Neurology, University of Texas MedicalSchool, Houston, Texas 77030, USA tCenter for Immigration Research, University of Houston, Houston, Texas 77204, USA 